\title{
EVALUASI KUALITAS WARNA IKAN KLOWN Amphiprion percula Lacepède 1802 TANGKAPAN ALAM DAN HASIL BUDIDAYA
}

\author{
Sukarman ${ }^{* * * * * \#}$, Dewi Apri Astuti ${ }^{* * *}$, dan Nur Bambang Priyo Utomo \\ *) Balai Riset Budidaya Ikan Hias \\ * Program Master Ilmu Nutrisi dan Pakan, Sekolah Pasca Sarjana, Institut Pertanian Bogor \\ ${ }^{* * *}$ Departemen IImu Nutrisi dan Pakan, Fakultas Peternakan, Institut Pertanian Bogor \\ **a*) Departemen Budidaya Perairan, Fakultas Perikanan dan IImu Kelautan, Institut Pertanian Bogor
}

(Naskah diterima: 13 Juli 2017; Revisi final: 18 September 2017; Disetujui publikasi: 18 September 2017)

\begin{abstract}
ABSTRAK
Kualitas warna ikan klown hasil budidaya lebih rendah dibandingkan tangkapan alam, hal ini dipengaruhi oleh berbagai faktor, namun belum ada data ilmiah sebagai dasar untuk melakukan perbaikan. Tujuan penelitian adalah menganalisis dan mengevaluasi kualitas warna ikan klown (Amphiprion percula) hasil tangkapan alam dibandingkan dengan hasil budidaya. Kualitas warna diukur pada dua zona: zona-l kulit berwarna oranye antara insang dengan band warna putih pada tengah badan dan zona-ll adalah bagian kulit warna oranye antara band putih tengah badan dengan band warna putih pada pangkal ekor, dengan parameter nilai L* (lightness), a* (redness), b* (yellowness), C (chroma), H (Hue). Analisis total karotenoid (TC) dilakukan pada kulit kedua zona, sirip pektoral, sirip dorsal, sirip kaudal, dan serum darah. Analisis kromatografi lapis tipis (KLT) dilakukan pada kulit dan sirip untuk mengonfirmasi jenis karotenoid dalam kulit dan sirip. Data kualitas warna dianalisis menggunakan t-test, hubungan kualitas warna dengan TC dianalisis dengan regresi sederhana, dan analisis deskriptif untuk hasil KLT. Hasil penelitian menunjukkan bahwa kualitas warna ikan klown tangkapan alam lebih baik dibanding budidaya, didukung oleh tingginya total karotenoid pada kulit zona-I, kulit zona-II, sirip pektoral, sirip dorsal, sirip kaudal, dan serum darah berturut-turut 51,64; 51,24; 136,40; 124,37; 194,18 mg/kg; dan 2,2 $\mu \mathrm{g} / \mathrm{mL}$; pada ikan hasil budidaya berurut-turut 2,5; 3,5; 8,45; 10,01; 23,43 mg/kg; dan 0,8 $\mu \mathrm{g} / \mathrm{mL}$. Hasil KLT menunjukkan bahwa jenis karotenoid pada kulit dan sirip ikan klown adalah astaxanthin, serta satu jenis karotenoid diduga zeaxanthin. Berdasarkan hasil penelitian, maka perlu ditambahkan pigmen karotenoid, dan prekursor pigmen lainnya melalui pakan untuk ikan klown budidaya.
\end{abstract}

\section{KATA KUNCl: astaxanthin; karotenoid; klown; zeaxanthin}

ABSTRACT: Color quality evaluation of wild and cultured clownfish (Amphiprion percula Lacepède 1802). By: Sukarman, Dewi Apri Astuti, and Nur Bambang Priyo Utomo

The color quality of cultured clownfish is not as good as the wild one. However, it's influenced by several factors. However, but there is not enough scientific data to be used as the basis for improvement. The purpose of this study was to analyze and evaluate the color quality difference between cultured and wild clown fish Amphiprion percula. Color qualities were measured in two zones: an orange-colored at zone-I was measured between gills and white band at the center of the body and an orange-colored at zone-II was measured between the center of white band and white band near the caudal peduncle. Parameters analyzed were L* (lightness), a* (redness), b* (yellowness), C (Chroma), H (Hue). Total carotenoid (TC) was analyzed on both zones-I and II, pectoral-fins, dorsal-fin, caudal-fin, and blood serum. Thin layer chromatography (TLC) was used to analyze the type of carotenoids in the skin and fin tissues. Color quality data was analyzed by T-test. Simple linier regression and descriptive analyses were used to analyzed theother parameters. The results showed that the color quality of wild clown fish was better than that of the cultured clown fish, indicated by high TC content in skin of zone-l, skin of zone-ll, pectoral-fin, dorsal-fin, caudal-fin, and blood serum (51.64, $51.24,136.40,124.37,194.18 \mathrm{mg} / \mathrm{kg}$, and $2.2 \mu \mathrm{g} / \mathrm{mL}$, respectively); and in cultured fish $2.5,3.5,8.45,10.01$,

\# Korespondensi: Balai Riset Budidaya Ikan Hias. Jl. Perikanan

No. 13, Pancoran Mas, Depok 16436, Indonesia.

Tel. + 62217520482

E-mail: carman_gbg@yahoo.com 
$23.43 \mathrm{mg} / \mathrm{kg}$, and $0.8 \mu \mathrm{g} / \mathrm{mL}$, respectively. TLC test results showed that carotenoid type in skin and fin of clownfish were astaxanthin, and one type of carotenoid was suspected as zeaxanthin. Based on the results of the study, it is necessary to add carotenoid pigments, especially astaxanthin or other precursor the feed to improve the color quality of cultured clown fish.

\section{KEYWORDS: astaxanthin; carotenoid; clownfish; zeaxanthin}

\section{PENDAHULUAN}

Warna merupakan aspek penting dan sangat berpengaruh terhadap nilai jual ikan hias (Ahilan et al., 2008; Singh \& Kumar, 2016; Sun et al., 2012; Wang et al., 2006; Yuangsoi et al., 2010). Umumnya warna ikan hias yang dipelihara di akuarium mengalami penurunan kualitas dibandingkan hasil tangkapan alam (Ako et al., 2012; Uthayasiva, 2014). Hal serupa juga terjadi pada ikan hasil tangkapan alam yang dipelihara di akuarium (Ezhil et al., 2008), namun demikian perbedaan kualitas warna pada beberapa spesies belum didukung dengan data-data ilmiah, sehingga sulit membuat strategi dalam mengatasi masalah tersebut.

Salah satu spesies ikan hias yang mengalami penurunan kualitas warna pada saat dipelihara di akuarium adalah Amphiprion percula Lacepède 1802. Setiawati et al. (2016) menambahkan bahwa benih A. percula hasil pemijahan di hatcheri memiliki warna oranye pucat, padahal warna oranye mendominasi bagian tubuh spesies ini. Permasalahan ini sudah diketahui, namun belum ada data ilmiah yang dapat dijadikan dasar untuk memperbaiki warna oranye pada spesies A. percula.

Penelitian tentang penutupan pola warna ikan A. percula telah dilakukan oleh Kusumah et al. (2015), tetapi belum menjelaskan kualitas dan bagaimana cara meningkatkannya, padahal menurut Sembiring et al. (2013) syarat kualitas warna ikan klown untuk ekspor adalah warna oranye pekat dengan pita hitam tebal, artinya kualitas warna oranye harus benar-benar diperhatikan. Oleh karena itu, masih diperlukan evaluasi kualitas warna terkait warna ikan klown.

Tujuan penelitian adalah menganalisis dan mengevaluasi kualitas warna antara A. percula tangkapan alam dibandingkan dengan hasil budidaya. Hasil penelitian bermanfaat untuk menentukan strategi peningkatan kualitas warna ikan A. percula di lingkungan budidaya.

\section{BAHAN DAN METODE}

Ikan uji yang digunakan adalah ikan A. percula strain normal hasil tangkapan alam (panjang total 5,25 \pm $0,49 \mathrm{~cm}$; bobot badan 2,59 $\pm 0,81 \mathrm{~g} / \mathrm{ekor}$ ) sejumlah 43 ekor berasal dari pengumpul ikan hias laut di Jakarta, dan hasil budidaya (panjang total 4,87 \pm 0.39 $\mathrm{cm}$, bobot badan 2,27 $\pm 0,55$ g/ekor) berasal dari Balai Besar Perikanan Budidaya Laut, Lampung.
Kualitas warna dianalisis pada dua zona kulit, menggunakan kolorimeter (Minolta Chroma CR-400, Osaka Japan), berdasarkan sistem warna CIE L*a*b* (CIE LAB) dengan parameter lightnes $\left(\mathrm{L}^{*}\right)$, redness $\left(\mathrm{a}^{*}\right)$, yellowness (b*) (Skrede \& Storebakken, 1987). L* memiliki kisaran nilai 0 untuk hitam, hingga 100 untuk warna putih. Zona-I adalah bagian badan depan yang berwarna oranye, antara insang dengan strip putih di tengah badan, zona-Il adalah bagian badan warna oranye antara strip putih di tengah badan dengan strip putih di pangkal ekor (Gambar 1).

Parameter Chromaticity, a* menentukan kualitas warna merah jika bernilai positif, abu-abu jika bernilai 0 , dan hijau jika bernilai negatif; b* menentukan kualitas warna kuning jika bernilai positif, abu-abu jika bernilai 0 , dan biru jika bernilai negatif. Hue $(H)$ dan Chroma $(\mathrm{C})$ dihitung berdasarkan rumus $\mathrm{H}=$ arc $\tan \left(b^{*} / a^{*}\right)$ dan $C=\left(a^{*}+b^{* 2}\right)^{1 / 2}$. Hue $(H)$ merupakan jenis warna pada objek pengukuran (seperti kuning, merah, atau hijau), dan Chroma (C) adalah kepekatan warna, semakin tinggi nilai chroma semakin pekat warna suatu objek.

Kandungan total karotenoid (TC) jaringan ikan diekstraksi menggunakan metode Teimouri et al. (2013a). Sampel kulit/sirip/ekor diambil dari dua bagian depan (zona-1) dan bagian belakang (zona-2), sedangkan sampel sirip yang dianalisis adalah sirip pektoral (1), sirip dorsal (2), dan sirip kaudal (3). Total karotenoid dalam serum darah dianalisis menggunakan metode Teimouri et al. (2013b). Uji kromatografi lapis tipis (KLT) dilakukan dengan mengekstrak karotenoid dari bagian kulit dan ekor yang diperoleh, ditotolkan sebanyak $20 \mu \mathrm{L}$ pada lempeng silica gel $60 \mathrm{GF}_{254}$, kemudian dielusi dengan fraksi gerak n-heksan-kloroform-aceton dengan rasio 6:2:2 (Kusmiati et al., 2010).

Analisis data kualitas warna dan total karotenoid dilakukan menggunakan T-test. Analisis regresi sederhana untuk antara parameter kualitas warna dengan karotenoid, dan data KLT dijelaskan secara deskriptif.

\section{HASIL DAN BAHASAN}

\section{Kualitas Warna Ikan A. percula}

Hasil pengukuran kualitas warna menunjukkan bahwa data masing-masing parameter sangat 


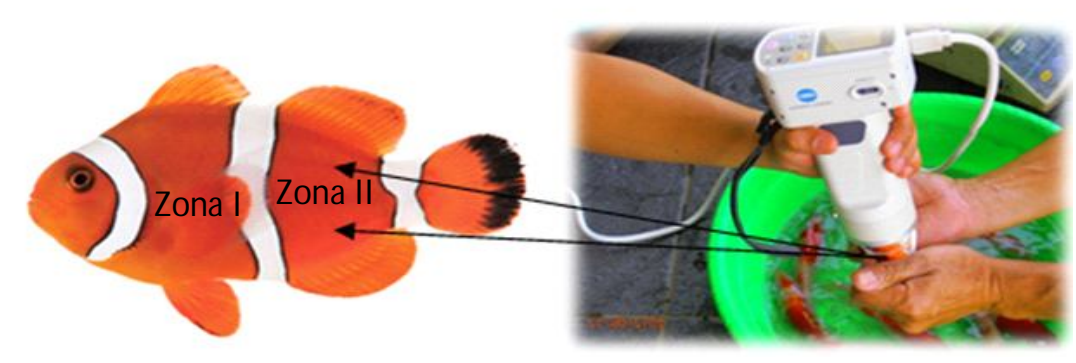

Gambar 1. Pengukuran warna pada ikan klown Amphiprion percula.

Figure 1. Color measurement for clown fish Amphiprion percula.

bervariasi. Hal tersebut disebabkan oleh berbagai faktor, sebagaimana dijelaskan oleh Meyer \& Latscha (1997) bahwa warna pada ikan dan krustasea dipengaruhi oleh pigmen, pakan, faktor internal hewan tersebut, lingkungan, dan penyakit. Variasi data hasil penelitian ini lebih rendah dibandingkan laporan Kusumah et al. (2015), disebabkan oleh perbedaan sistem warna dan cara pengukuran yang digunakan yaitu sistem warna HSB dengan metode pengukuran menggunakan foto digital, sedangkan pada penelitian ini sistem warna yang digunakan adalah sistem CIE $L A B$ dengan pengukuran langsung pada ikan menggunakan kolorimeter pada badan ikan. Data kualitas warna oranye ikan A. percula populasi alam dan hasil budidaya disajikan pada Tabel 1.

Analisis T-test pada parameter $L^{*}$ menunjukkan bahwa nilai zona-II ikan budidaya lebih tinggi dan berbeda $(P=0,000)$ dibandingkan zona-ll ikan alam dan zona-l, baik ikan alam maupun budidaya. Artinya warna oranye ikan A. percula pada badan bagian belakang (zona-II) hasil budidaya cenderung lebih terang dibandingkan pada bagian depan (zona-I), sedangkan perbandingan nilai L* pada ikan alam zona-I dibandingkan ikan hasil budidaya zona-l, ikan alam zona-I dibandingkan ikan alam zona-II, dan dan ikan budidaya zona-I dibandingkan ikan alam zona-II menunjukkan nilai yang tidak berbeda $(P>0,05)$. Simpson et al. (1981) menjelaskan bahwa warna kuning, oranye-merah pada ikan disebabkan oleh karotenoid yang disimpan dalam sel chomatofor. Sefc et al. (2014) menambahkan bahwa sel chromatofor yang dimaksud adalah jenis xanthofor dan erytrofor, namun pada spesies ini rendahnya nilai L* disebabkan adanya penutupan warna hitam pada bagian tertentu. Sebagaimana diketahui bahwa warna hitam merupakan ekspresi dari sel chromatofor jenis melanofor yang menyimpan melanin (Sköld et al., 2016). Penutupan warna hitam pada spesies ini dipengaruhi oleh faktor lingkungan terutama pencahayaan yang menginduksi pola pigmentasi melalui stimulus pada sistem neuron dan migrasi melanofor (Kusumawati et al., 2012).

Interfensi warna hitam ini diduga kuat dipengaruhi pigmen melanin, berupa eumelanin yang berwarna coklat tua-hitam (Sköld et al., 2016), dapat disintesis oleh hewan dari asam amino tyrosin, phenilalanin (McGraw, 2006), serta cysteine (Wakamatsu \& Ito,

Tabel 1. Kualitas warna oranye kulit ikan klown alam dan hasil budidaya

Table 1. Color quality of orange hue of the wild and cultured clownfish skin

\begin{tabular}{|c|c|c|c|c|}
\hline \multirow{2}{*}{$\begin{array}{l}\text { Parameter } \\
\text { Parameters }\end{array}$} & \multicolumn{2}{|c|}{ Zona-1 (Zone-l) } & \multicolumn{2}{|c|}{ Zona-II (Zonell) } \\
\hline & $\begin{array}{l}\text { Alam (Wild) } \\
(n=43)\end{array}$ & $\begin{array}{l}\text { Budidaya (Cultured) } \\
(n=53)\end{array}$ & $\begin{array}{c}\text { Alam (Wild) } \\
(n=43)\end{array}$ & $\begin{array}{l}\text { Budidaya (Cultured) } \\
\qquad(n=53)\end{array}$ \\
\hline L*(\%) & $37.2 \pm 5.15$ & $37.7 \pm 4.70$ & $36.3 \pm 4.37$ & $41.1 \pm 3.06$ \\
\hline$a^{*}$ & $15.1 \pm 5.69$ & $2.8 \pm 1.40$ & $15.8 \pm 4.35$ & $5.1 \pm 2.29$ \\
\hline$b^{*}$ & $22.9 \pm 10.68$ & $9.3 \pm 4.02$ & $23.4 \pm 6.73$ & $11.2 \pm 3.35$ \\
\hline$C(\%)$ & $27.4 \pm 11.92$ & $9.6 \pm 4.02$ & $28.5 \pm 7.85$ & $12.4 \pm 4.14$ \\
\hline$H\left(\left(^{\circ}\right)\right.$ & $56.1 \pm 5.45$ & $71.5 \pm 9.56$ & $55.8 \pm 5.56$ & $65.9 \pm 6.10$ \\
\hline
\end{tabular}


2002) menggunakan enzimtyrosinase melalui rangsangan pencahayaan radiasi ultraviolet cahaya matahari (Solano, 2014).

Perbedaan kualitas warna merah dan kuning pada ikan klown dijelaskan melalui parameter $a^{*}$ dan $b^{*}$. Redness value (a*) pada zona-I dan II ikan A. percula hasil tangkapan alam lima dan tiga kali lebih tinggi dibandingkan hasil budidaya, sedangkan yellowness value (b*) berturut-turut 2, 4, dan 2 kali lebih tinggi (Tabel 1). Berdasarkan hasil T-test, warna zona-I dan zona-II ikan hasil tangkapan alam yang tidak berbeda, baik nilai $a *(P=0,488)$ maupun nilai $b *(P=0,759)$, sedangkan jika dibandingkan dengan ikan budidaya $(P=0,000)$ nilainya lebih tinggi (Tabel 1$)$. Hal tersebut menunjukkan bahwa pigmen warna kuning dan merah lebih banyak terdapat pada ikan hasil tangkapan alam. Kondisi ini merupakan implikasi dari jenis pakan yang dikonsumsi, sebab ikan tidak mampu menyintetis pigmen di dalam tubuhnya (Goodwin, 1984) dan harus mendapatkan pigmen dari zooplankton dan fitoplankton (Matsuno et al., 1999), yang mengandung karotenoid berupa zeaxanthin, lutein, dan astaxanthin (Matsuno, 2001), membuat warna kulit ikan A. percula tangkapan alam mempunyai warna kuning hingga oranye, dengan distribusi warna ditampilkan pada Gambar 2. Kondisi tersebut berbeda dengan ikan hasil budidaya.
Nilai chroma pada zona-I dan zona-II ikan hasil tangkapan alam relatif sama $(P=0,545)$, namun lebih tinggi dibandingkan dengan ikan budidaya $(P=0,000)$. Tingginya nilai chroma menunjukkan semakin banyaknya timbunan pigmen karotenoid padajaringan (Guillaume et al., 2001), baik pigmen merah yang direfleksikan melaui $a^{*}$ maupun pigmen kuning ( $b *$ ). Semakin tinggi $a^{*}$ dan $b^{*}$ maka warna oranye semakin pekat, meskipun tingkat iluminitasnya (L*) berbeda.

Berdasarkan jenis warnanya, ikan hasil tangkapan alam lebih oranye dibandingkan dengan hasil budidaya, baik di zona-I maupun di zona-II, hal ini diindikasikan dengan lebih rendahnya nilai Hue $(P=0,000)$. Warna paling oranye ditunjukkan pada zona-II ikan alam dengan nilai Hue sebesar $55,8^{\circ}$; lebih tinggi dibandingkan dengan laporan Kusumah et al. (2015) sebesar $19^{\circ}-33^{\circ}$ pada ikan A. percula hasil tangkapan alam. Perbedaan ini disebabkan oleh asal ikan dan jenis pakan yang dikonsumsi di habitatnya. Menurut Ho et al. (2014), nilai Hue dipengaruhi oleh jenis pakan, dan interaksi jenis pakan dengan waktu mengonsumsinya. Hal tersebut juga sejal an dengan hasil penelitian Yasir \& Qin (2010), yang menjelaskan bahwa ikan klown yang diberi pakan astaxanthin selama lima minggu menurunkan nilai Hue, sehingga warnanya menjadi lebih merah.

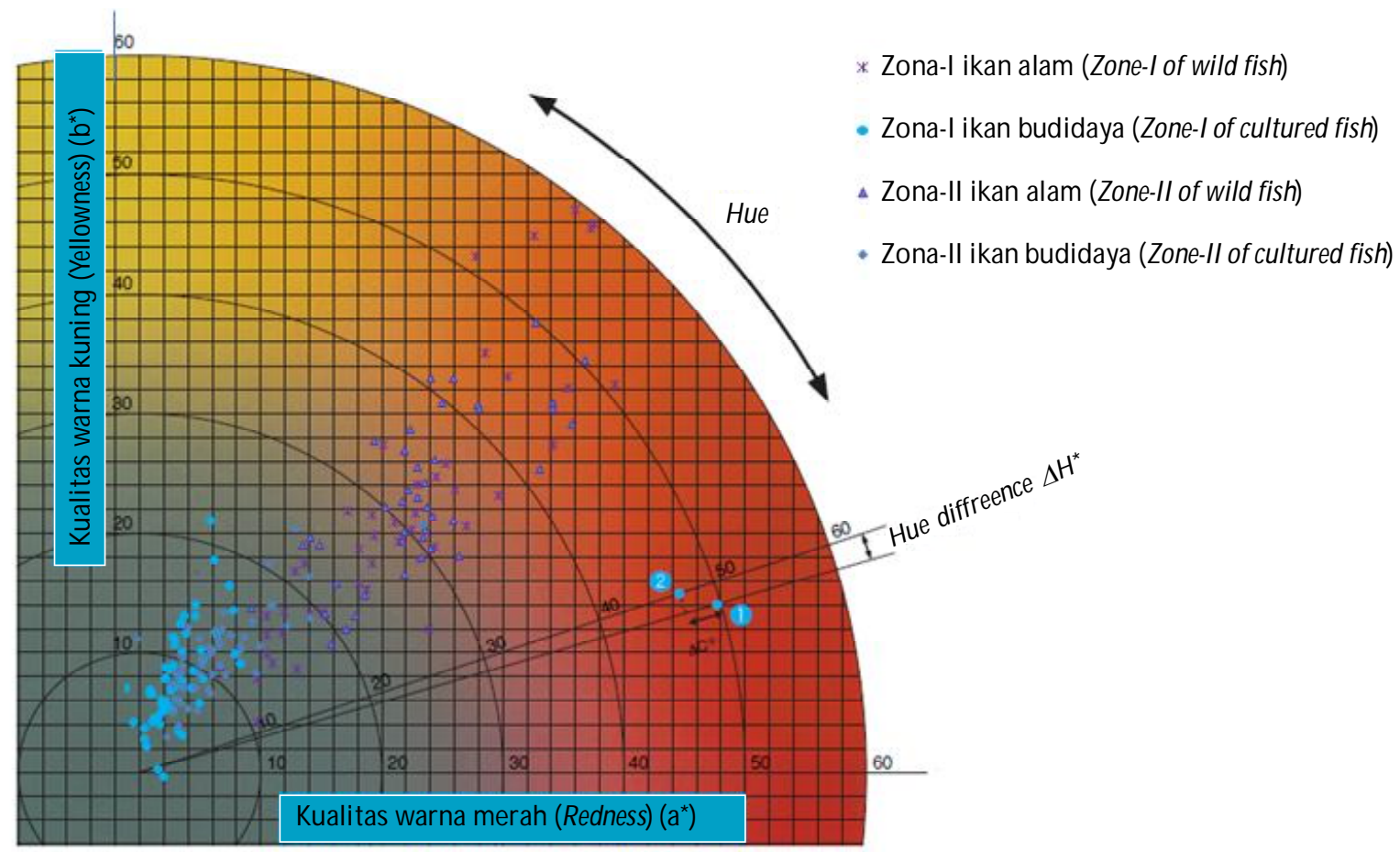

Gambar 2. Distribusi warna kulit ikan A. percula alam dan budidaya. Figure 2. Distribution of skin color of wild and cultured A. percula. 


\section{Total Karotenoid (TC) dalam Jaringan Tubuh Ikan A. percula}

Bukti adanya karotenoid dalam kulit yang direfleksikan dalam nilai a*dan b*, telah dikonfirmasi dengan melakukan analisis karotenoid pada berbagai jaringan tubuh ikan A. percula. Data TC pada kulit (zonaI dan zona-II), sirip pectoral, sirip dorsal, dan sirip kaudal ditampilkan pada Gambar 3.

Kandungan total karotenoid tertinggi terdapat pada bagian sirip caudal, diikuti sirip pektoral, sirip dorsal, dan kulit baik untuk ikan alam maupun hasil budidaya. Secara umum, kandungan total karotenoid pada seluruh jaringan $A$. percula alam lebih tinggi dibandingkan hasil budidaya, memperkuat bahwa warna pada A. percula dipengaruhi oleh karotenoid.

Hubungan antara total karotenoid terhadap warna oranye (Hue) kulit ikan $A$. percula bersifat linier negatif $\left(Y=-0,3597 x+71.889 ; R^{2}=0,663 \%\right.$ P value $\left.=0,000\right)$ (Gambar 3), artinya setiap kenaikan karotenoid sejumlah satu satuan akan mengurangi nilai Huesebesar $0,3597^{\circ}$. Menurunnya nilai Hue dari kisaran $90^{\circ}$ hingga $0^{\circ}$ menunjukkan perubahan jenis warna dari kuningoranye hingga merah (Sukarman et al., 2014). Model hubungan antara total karotenoid dengan Hue mendekati hasil penelitian $\mathrm{Ho}$ et al. (2013) pada ikan A. occelaris yaitu $Y=-68,748 x+27,423 ; R^{2}=0,689 \%$ $P$-value $=0,000$. Perbedaan ini oleh faktor genetik, keduanya merupakan dua spesies yang berbeda dalam satu genus. Data ini selaras dengan hasil penelitian Teimori et al. (2013b) yang menjelaskan bahwa hubungan antara konsentrasi karotenoid dengan nilai Hue pada ikan salmon $\left(Y=-0,1065 x+4,2966 ; R^{2}=\right.$ $0,142 ;$ P-value $=0,166)$. Berdasarkan hal tersebut dapat diketahui bahwa semakin banyak total karotenoid di dalam kulit, warna ikan A. percula semakin merah.

Menurut Matsuno (2001), warna merah dihasilkan oleh karotenoid astaxanthin (merah muda), cantaxanthin (merah), lutein (kuning), betakaroten (oranye), dan zeaxanthin (oranye), karena Amphiprion sp. merupakan ikan jenis omnivora (Setiawati et al., 2016) yang mempunyai kemampuan menyimpan astaxanthin, cantaxanthin, dan mampu mengonversi lutein, zeaxanthin, serta sedikit betakaroten menjadi astaxanthin (Latscha, 1990). Hal tersebut yang menyebabkan nilai Hue dari A. percula beragam dari kuning hingga merah. Selain itu, warna merah juga dapat disebabkan karena adanya pteridin pada sel

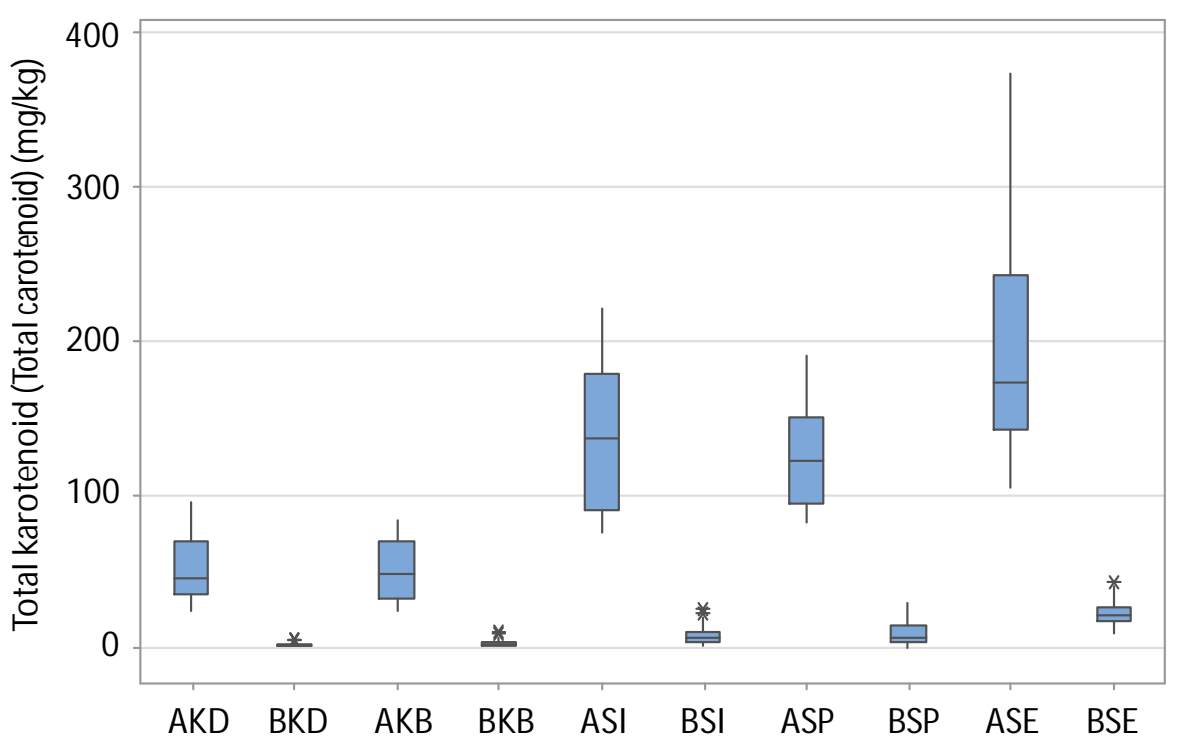

Gambar 3. Konsentrasi total karotenoid pada jaringan tubuh ikan A. percula, $A K D=$ kulit zona-I ikan alam, BKD= kulit zona-I ikan budidaya, $A K B=$ kulit zona-II ikan alam, BKD= kulit zona-II ikan budidaya, $\mathrm{ASI}=$ sirip pektoralikan alam, BSI = sirip pectoral ikan budidaya, $\mathrm{ASP}=$ sirip dorsal ikan alam, $\mathrm{BSP}=$ sirip dorsal ikan budiadaya, $\mathrm{ASE}=$ sirip caudal ikan alam, BSE = sirip caudal ikan budidaya .

Figure 3. Concentrations of total carotenoids in the tissue of clownfish, $A K D=$ skin of zone-l wild fish, $B K D=$ skin of zone-l cultured fish, $A K B=$ skin zone-II of wild fish, $B K D=$ zone-II of farmed fish, $A S I=$ pectoral fin of wild fish, $B S I=$ pectoral fin of cultured fish, $A S P=$ dorsal fin of wild fish, $B S P=$ dorsal fin of farmed fish, $A S E=$ caudal fin of wild fish, $\mathrm{BSE}=$ caudal fin of cultured fish. 
erytrofor (Maan \& Sefc, 2013), kemungkinkan diinterfensi oleh pheomelanine yang berwarna kuning-coklat kemerahan (Ito et al., 2000), atau eumelanin yang berwana hitam (Skold et al., 2016) sehingga warna ikan menjadi lebih gelap.

Meskipun demikian, dalam sistem warna CIE L*a*b* dapat diduga jenis warna karotenoid dalam kulit ikan A. percula dominan merah atau kuning dengan melakukan analisis regresi sederhana. Hasil analisis regresi diketahui bahwa model hubungan antara TC pada kulit dengan nilai $a^{*}$ (redness) mempunyai $\mathrm{R}^{2}$ lebih tinggi dibandingkan model hubungan antara TC dengan b* (yellowness), di mana kedua model bersifat positif (Gambar 4b). Hal tersebut selaras dengan laporan Safari \& Atash (2015) dan Teimori et al. (2013b), bahwa regresi hubungan antara konsentrasi karotenoid bernilai positif dan lebih memengaruhi warna merah dibandingkan warna kuning daging ikan salmon. Berdasarkan hal tersebut dapat diduga bahwa tipe karotenoid berwarna merah merupakan jenis yang dominan dalam kulit A. percula, dan ada kemungkinan pigmen yang berwarna kuning dikonversi menjadi warna merah sebelum disimpan dalam kulit ikan, sebagaimana disampaikan Latscha (1990) bahwa jenis ikan omnivor mempunyai kemampuan yang tinggi dalam mengonversi berbagai jenis karotenoid lutein (kuning) dan zeaxanthin (kuning-oranye) menjadi jenis astaxanthin (merah).
Secara kualitatif jenis karotenoid dapat diketahui melalui analisis kromatografi lapis tipis (KLT). Hasil penelitian menunjukkan bahwa terdapat karotenoid astaxanthin ( $\mathrm{Rf}=0,45)$ pada sampel sirip dan kulit ikan A. percula hasil tangkapan alam, namun tidak terdeteksi pada ikan hasil budidaya (Gambar 5), menunjukkan bahwa terdapat astxanthin di dalam jaringan yang diuji. Nilai Rf astaxanthin, berbeda dengan laporan Yuangsoi et al. (2011), yaitu sebesar 2,0; disebabkan oleh perbedaan fase gerak yang digunakan dalam analisis. Selain itu, terdeteksi adanya karotenoid jenis lainnya pada sirip dan kulit ikan hasil tangkapan alam ( $R f=0,29)$. Hal tersebut menunjukkan bahwa ikan A. percula menyimpan karotenoid dalam bentuk selain astaxanthin, namun bukan dalam bentuk cantaxanthin, lutein, dan $\beta$-karoten.

Hasil penelitian ini berbeda dengan laporan Yasir \& Qin (2009) yang menyatakan bahwa jenis karotenoid dalam kulit ikan A. occelaris paling banyak berupa $\beta$ karoten yaitu lebih dari $80 \%$ diikuti, zeaxanthin, cantaxanthin, dan astaxanthin. Hasil penelitian justru lebih selaras dengan penelitian Ho et al. (2013), yang menunjukkan bahwa terdapat dua jenis karotenoid paling banyak pada A. occelaris berupa astaxanthin dan 4-hydroksizeaxanthin pada kulit ikan klown A. occelaris, dan hanya sedikit terdapat lutein, serta $\beta$-karoten; karena $\beta$-karoten sebagian besar dikonversi menjadi vitamin A di dalam usus hewan.

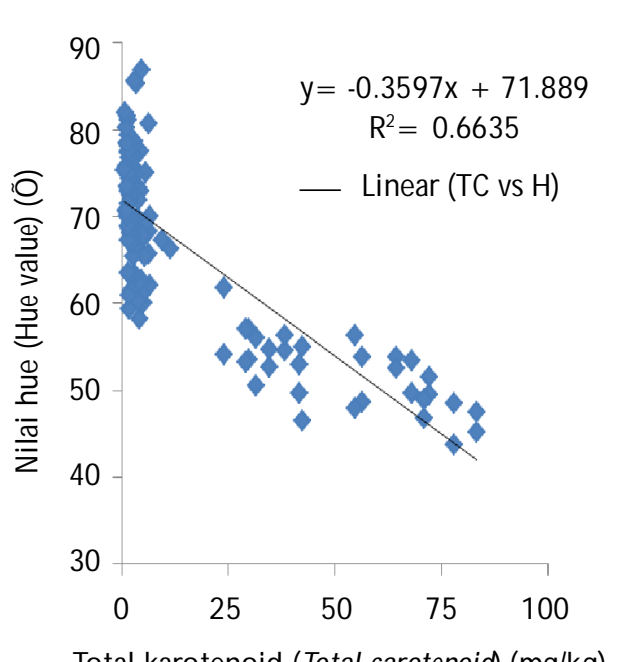

Total karotenoid (Total carotenoid) $(\mathrm{mg} / \mathrm{kg}$ )

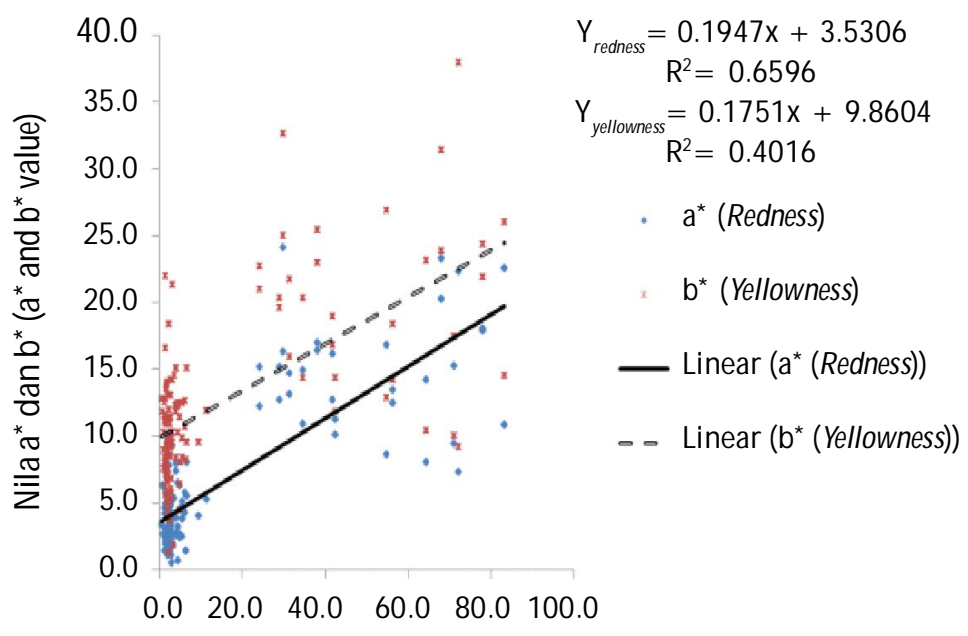

Total karotenoid (Total carotenoid) $(\mathrm{mg} / \mathrm{kg})$

Gambar 4. Hubungan antara kandungan total karotenoid dengan nilai Hue pada ikan A. percula, (a), hubungan antara kandungan total karotenoid pada kulit dengan nilai a* dan b* pada ikan A percula (b).

Figure 4. Corelation of total carotenoid concentration with hue in $\mathbf{A}$. percula fish (a), corelation of total carotenoid concentration in fish skin with $a^{*}$ and $b^{*}$ value of $\mathbf{A}$. percula fish (b). 


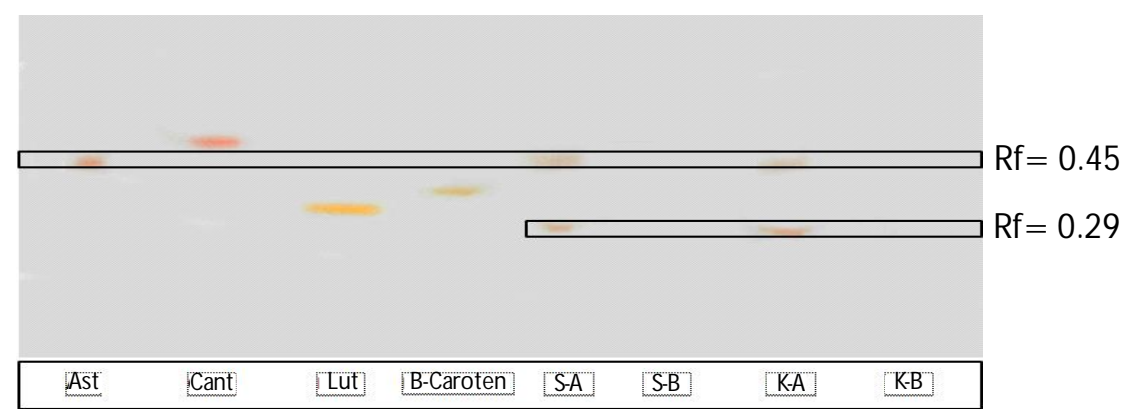

Gambar 5. Hasil uji kromatografi lapis tipis $(\mathrm{KLT})$, Ast= standar astaxanthin, Cant $=$ standar cantaxanthin, Lut= standar lutein, $\beta$-karoten $=$ standar $\beta$-karoten, $S-A=$ sampel sirip ikan alam, S-B= sampel sirip ikan budidaya, $\mathrm{K}-\mathrm{A}=$ sampel kulit ikan alam, $\mathrm{K}-\mathrm{B}=$ sampel kulit ikan budidaya.

Figure 5. Result of thin layer chromatogrhapy test $(\mathrm{TLC})$, Ast= astaxanthin standard, Cant = cantaxanthin standard, Lut= lutein standard, $\beta$-caroten $=\beta$-caroten standard, $\mathrm{S}-\mathrm{A}=$ fin of wild fish, $\mathrm{S}-\mathrm{B}=$ fin of cultured fish, $K-A=$ skin of wild fish, $K-B=$ skin of cultured fish.

Karotenoid yang terdapat dalam kulit, sirip, dan ekor ikan pada dasarnya berasal dari makanannya, karena pigmen tersebut hanya diproduksi oleh tumbuhan, alga, dan mikroorganisme yang mempunyai kemampuan melakukan fotosintesis (Dharmaraj \& Dhevendaran, 2011). Analisis karotenoid dalam darah telah dilakukan untuk memastikan hal tersebut. Hasil penelitian menunjukkan bahwa total karotenoid dalam serum darah ikan hasil tangkapan alam sebesar 2,2 $\mu \mathrm{g} / \mathrm{mL}$; lebih tinggi dibandingkan karotenoid dalam serum ikan hasil budidaya $(0,8 \mu \mathrm{g} / \mathrm{mL})$ sebagaimana disajikan dalam Gambar 6.
Hasil penelitian sesuai dengan laporan Yuangsoi et al. (2010) bahwa kandungan TC pada serum ikan koi yang diberi pakan tanpa karotenoid sebesar 0,86-1,1 $\mu \mathrm{g} / \mathrm{mL}$; setelah diberi pakan berkarotenoid sebesar $1,3-9,31 \mu \mathrm{g} / \mathrm{mL}$ tergantung pada dosis dan lama pemberiannya. Sementara itu, menurut Guillaume et al. (2001), TC dalam serum ikan salmon sebelum diberi pakan karotenoid berkisar 0,8-2,0 $\mu \mathrm{g} / \mathrm{mL}$ dan sesudah diberi astaxanthin meningkat menjadi $6,0-12,0 \mu \mathrm{g} / \mathrm{mL}$. Berdasarkan hasil tersebut dapat diduga bahwa tingginya karotenoid dalam serum ikan hasil tangkapan alam berasal dari karotenoid dalam pakan yang

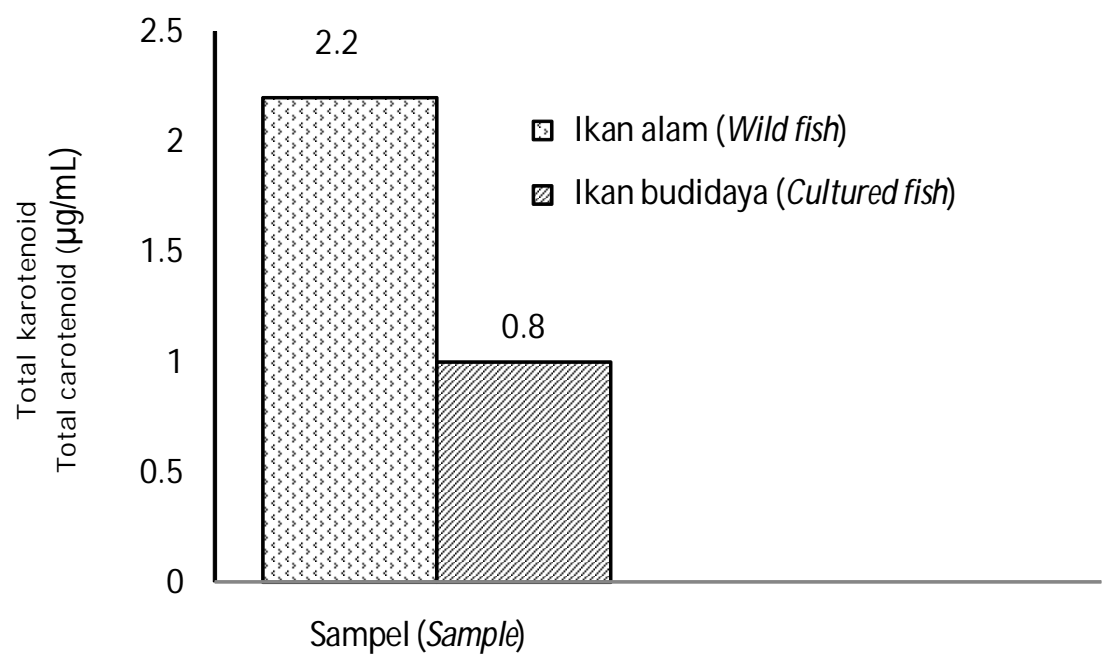

Gambar 6. Total karotenoid pada serum ikan A. percula.

Figure 6. Total carotenoids in A. percula fish serum. 
dikonsumsi di habitat aslinya, sedangkan pada ikan budidaya terbatas pada pakan yang diberikan selama masa pemeliharaan.

\section{KESIMPULAN}

Kualitas warna ikan Amphiprion percula hasil tangkapan alam lebih baik dibandingkan hasil budidaya, disebabkan oleh tingginya karotenoid pada jaringan kulit, sirip, dan serum darah yang diperoleh dari makanannya.

\section{UCAPAN TERIMA KASIH}

Ucapan terima kasih kepada Balai Riset Budidaya Ikan Hias, Kementerian Kelautan Perikanan yang telah memfasilitasi kegiatan penelitian ini.

\section{DAFTAR ACUAN}

Ahilan, B., Jegan, K., Felix, N., \& Raveneswaran, K. (2008). Influence of botanical additives on the growth and coloration of adult goldfish. Tamil Nadu J. Vetenary Animal Science, 4(4), 129-134.

Ako, H., Tamaru, C.S., \& Yamamoto, M. (2012). Achieving natural coloration in fish under culture. UNJR Tech Report, 28, 1-4.

Dharmaraj, S., \& Dhevendaran, K. (2011). Application of microbial carotenoids as a source of colouration and growth of ornamental fish Xiphophorus helleri. World Journal Fish Marine Science, 3(2), 137-144.

Ezhil, J., Jeyanthi, C., \& Narayanan, M. (2008). Marigold as carotenoid source on pigmentation and growth red swordtail, Xiphoporus helleri. Turkish Journal of Fisheries and Aquatic Science, 8, 99-102.

Goodwin, T.W. (1984). The biochemistry of carotenoids. 2nd ed. London: Chapman \& Hall.

Guillaume, J., Kaushik, S., Bergot, P., \& Métailler, R. (2001). Nutrition and feeding of fish and crustacean (408 pp). Chichester: Praxis Publishing Ltd.

Ho, A.L.F.C., Zong, S., \& Lin, J. (2014). Skin color retention after dietary carotenoid deprivation and dominance mediated skin coloration in clownfish, Amphiprion ocellaris. AACL Bioflux, 7(2), 103-115.

Ho, A.L.F.C., Bertran, N.M.O., \& Lin, J. (2013). Dietary esterified astaxanthin concentration effect on dermal coloration and chromastophore physiology in spinecheek anemonefish, Premnas biaculeatus. Journal Wold Aquaculture Society, 44(1), 76-85.

Ito, S., Wakamatsu, K., \& Ozeki, H. (2000). Chemical analysis of melanins and its application to the study of the regulation of melanogenesis, Pigment Cell. Ress., 13, 103-109.
Kusumah, R.V., Cindelaras, S., \& Prasetio, A.B. (2015). Keragaan warna ikan clown biak (Amphiprion percula) populasi alam dan budidaya berdasarkan analisis gambar digital. J. Ris. Akuakultur, 10(3), 345355.

Kusumawati, D., Permana, S., Setiawati, K.H., \& Haryanti. (2012). Peran gen AIM1 dan intensitas cahaya terhadap karakter pola pigmen ikan badut hitam (Amphiprion percula). J. Ris. Akuakultur, 7(2), 205-219.

Kusmiati, Agustini, N.W.S., Tamat, S.R., \& Irawati, M. (2010). Ekstraksi dan purifikasi senyawa lutein dari mikroalga Chlorella pyrenoidosa galur lokal INK. Jurnal Kimia Indonesia, 5(1), 30-34.

Latscha, T. (1990). Carotenoid in animal nutrition: their nature and significance in the animal feeds. Roche publication, No. 2175, F. Hoffmann-La Roche, Animal Nutrition and Health, Basel, Switzerland.

Maan, M.E., \& Sefc, K.M. (2013). Colour variation in cichlid ûsh: developmental mechanisms, selective pressures and evolutionary consequences. Seminar in Cell Development Biology, 24, 516-528.

Matsuno, T., Ohkubo, M., Toriiminami, Y., Tsuhima, M., Sakaguchi, S., Minami, T., \& Makoa, T. (1999). Carotenoid in food chain between fresh water fish and aquatics insect. Comparative Biochemistry and Physiology Part B, 124, 341-345.

Matsuno, T. (2001). Aquatic animal carotenoid. Fisheries Sci., 67, 771-783.

McGraw, K.J. (2006). Dietary mineral content influences the expression of melanin-based ornamental coloration. Behavioral Ecology, 18(1), 137-142.

Meyer, S.P., \& Latscha, T. (1997). Carotenoids. In Crustacean Nutrition, Advance in World Aquaculture, 6, 164-193. Abramo, L.R.D.', Conklin, D.E., \& Akiyama, D.M. (Eds.). Baton Rouge. LA: World Aquaculture Society.

Safari, O., \& Atash, M.M.S. (2015). The effects of dietary supplement of annatto (Bixa orellana) seed meal on blood carotenoid content and ûllet color stability in rainbow trout (Oncorhynchus mykiss). Aquaculture, 437, 275-281.

Sefc, K.M., Brown, A.C., \& Clotfelter, E.D. (2014). Carotenoid-based coloration in cichlid fishes. Compilation Biochemistry Physiology, Part A, 173, 4251.

Sembiring, S.B.M., Setiawati, K.M., Hutapea, J.H., \& Subamia, W. (2013). Pewarisan pola warna ikan klown biak Amphiprion percula. Jurnal Ilmu dan Teknologi Kelautan Tropis, 5(2), 343-351.

Setiawati, K.M., Gunawan, \& Hutapea, J.H. (2016). Pemeliharaan larva ikan klown (Amphiprion percula) 
dengan pakan alami berbeda. J. Ris. Akuakultur, 11(1), 67-73.

Simpson, K.L., Katayama, T., \& Chichester, C.O. (1981). Carotenoid in fish feeds. In Carotenoids as colorants and vitamin A precursors. (Eds.) Bauernfeind, J.C. New York: Academic Press Inc., p. 463-538.

Singh, R.N., \& Kumar, A. (2016). Beetroot as a carotenoid source on growth and color development in Red Swordtail (Xiphophorushelleri) fish. Imperial Journal of Interdiscliplinary Research, 2(10), 637-642.

Skçld, H.N., Aspengren, S., Cheney, K.L., \& Wallin, M. (2016). Fish chromatophores-from molecular motor to animal behavior. Int'l. Rev. Cell. Mol. Bio., 32, 171-199.

Skrede, G., \& Storebakken, T. (1987). Characteristics of colour in raw, baked and smoked wild and penreared Atlantic salmon. J. Food Sci. Tech., 5, 123134.

Solano, F. (2014). Melanins/ : in pigments and much more-types, structural models, biological functions, and formation routes. New Journal Science, $28 \mathrm{pp}$.

Sukarman, Hirnawati, R., Subandiyah, S., Meilisza, N., \& Subamia, I W. (2014). Penggunaan tepung bunga marigold dan tepung Haematococcus pluvialis sebagai sumber karotenoid pengganti astaxanthin untuk meningkatkan kualitas warna ikan Koi. J. Ris. Akuakultur, 9(2), 237-249.

Sun, X., Chang, Y., Ye, Y., Ma, Z., Liang, Y., Li, T., Jiang, N., Xing, W., \& Luo, L. (2012). The effect of dietary pigments on the coloration of Japanese ornamental carps (Koi, Cyprinus carpio L.). Aquaculture, 342-343, 62-68.
Teimouri, M., Amirkolaie, A.K., \& Yeganeh, S. (2013a). The effects of dietary supplement of Spirulina platensis on blood carotenoid concentration and fillet color stability in rainbow trout (Oncorhynchus mykiss). Aquaculture, 414-415, 224-228.

Teimouri, M., Amirkolaie, A.K., \& Yeganeh, S. (2013b). The effects of Spirulina platensis meal as a feed supplement on growth performance and pigmentation of rainbow trout (Oncorhynchus mykiss). Aquaculture, 396-399, 14-19.

Uthayasiva, M. (2014). Significance of light intensity to enhance the colour of marine ornamental fish Amphiprion clarkii (Bennett, 1830) in captivity. Int'l. J. Fauna Bio. Studies, 1(4), 14-18.

Wakamatsu, K., \& Ito, S. (2002). Advance chamical methods in melanin determination. Pigment Cell. Res., 15, 174-183.

Wang, Y., Chien, Y., \& Pan. (2006). Effect of dietary suplementation of carotenoids on survival, growth, pigmentation and antioxidant capacity of charancis, Hyphessobrycon callitus. Aquaculture, 261, 641-648.

Yasir, I., \& Qin, J.G. (2009). Effect of light intensity on color performance of false clownfish, Amphiprion occelaris. Journal of the World Aquaculture Society, 40(3), 337-350.

Yuangsoi, B., Jintasataporn, O., Tabthipwon, P., \& Kamel, C. (2010). Ulitization of carotenids in fancy carp (Cyprinus carpio): astaxanthin, lutein \& - carotene. World Applied Science Journal, 11(5), 590-598.

Yuangsoi, B., Jintasataporn, O., Areechon, N., \& Tabthipwon, P. (2011). The pigmenting effect of different carotenoids on fancy carp (Cyprinus carpio). Aquaculture Nutrition, 17, e306-e316. 